УДК 342.95

DOI https://doi.org/10.32837/pyuv.v0i5(34).657

В. С. Князєв

orcid.org/0000-0002-3696-0746

кандидат юридичних наук

\title{
НОРМАТИВНО-ПРАВОВЕ РЕГУЛЮВАННЯ РЕАЛІЗАЦІЙНИХ ПРОЦЕДУР У ДІЯЛЬНОСТІ МИТНИХ ОРГАНІВ УКРАЇНИ
}

Актуальність теми дослідження. Митні органи України відповідно до покладених на них завдань зобов'язані проводити облік, зберігання, оцінку вилученого, прийнятого на зберігання, розміщеного у митний режим відмови на користь держави майна, а також майна, виявленого в зоні митного контролю, власник якого невідомий, та розпорядження ним. Також у випадках, передбачених законом, митні органи здійснюють провадження у справах про порушення митних правил та у справах про адміністративні правопорушення, що також може потягнути за собою надходження майна у розпорядження митних органів [1].

Активний розвиток інформаційних технологій створює нові можливості для здійснення повноважень митних органів України у частині реалізації майна, яке перебуває у їх розпорядженні. У грудні 2019 року КМУ підтримав розроблену Міністерством фінансів спільно з Державною фіскальною службою постанову щодо затвердження нового порядку реалізації товарів на митних аукціонах, редукціонах. Зокрема, у Постанові КМУ «Про затвердження Порядку реалізації товарів на митних аукціонах, редукціонах та визнання такими, що втратили чинність, деяких постанов Кабінету Міністрів України» від 4 грудня 2019 р. № 1050 йдеться про затвердження виключно електронного (онлайн) порядку реалізації товарів на митних аукціонах та редукціонах. Водночас Постанову КМУ «Про затвердження Порядку організації митних аукціонів, реалізації товарів і транспортних засобів на митних аукціонах, товарних біржах або через підприємства торгівлі, а також розпорядження окремими видами товарів, що не підлягають реалізації» № 607 від 26 квітня 2003 р. та інші постанови, якими до неї вносилися зміни, визнано такими, що втратили чинність. Новий порядок запроваджує сучасні електронні технології реалізації товарів, що перейшли у власність держави за порушення законодавства з питань митної справи, на митних аукціонах, редукціонах шляхом використання електронної торгової системи.

Відповідальним за забезпечення функціонування електронної торгової системи постановою передбачено визначити ДП «Прозорро.продажі». При цьому порядком передбачено процедури підготовки та проведення митних аукціонів та редукціонів, визначення переможця та оформлення результатів таких торгів тощо. Реалізація положень постанови дозволить підвищити відкритість та прозорість продажу товарів, що перейшли у власність держави за порушення законодавства з питань митної справи.

Водночас поширення нового нормативноправового порядку проведення митних аукціонів призвело до виникнення низки важливих питань щодо ефективності зазначених процедур. У зв'язку 3 цим дослідження питання ефективності чинних реалізаційних процедур, встановлення резервів i фактів їх покращення є надзвичайно актуальним.

Аналіз останніх досліджень. Питання щодо нормативно-правового регулювання процесу реалізації товарів (майна), які перебувають у розпорядженні органів державної влади, у тому числі сутності та видів товарів, що вилучаються чи приймаються на зберігання митницями, та операцій 3 ними висвітлювали у своїх роботах I. Бережнюк, Н. Білак, О. Вакульчик, П. Пашко, С. Терещенко, Л. Пісьмаченко, Л. Прус, А. Берзан, О. Грачов, Н. Жанарбаєва, М. Каленський, С. Коляда, У. Романюк, Є. Корнієнко, М. Разумей, Л. Пісьмаченко, Н. Єсипчук, Т. Єдинак, В. Фоменко та інші. Деякі проблеми, пов'язані з державним майном, досліджували у своїх працях А. Гальчинський, I. Лукінов, О. Пасхавер, М. Чечетов. Аналіз останніх досліджень і публікацій доводить недостатній рівень науково-теоретичного та практичного опрацювання проблематики ефективності нормативно-правовогорегулюваннявідносинзпроцесу реалізації товарів (майна), яке перебуває у розпорядженні митних органів.

Метою статті є визначення відповідності нормативно-правового регулювання процесу реалізації товарів (майна), яке перебуває у розпорядженні митних органів, сучасним суспільним потребам у цій частині здійснення державної митної політики. Результати дозволять отримати комплексне бачення проблеми та створять можливість до формування відповідних доктринальних та практичних пропозиції для його подальшого використання у практичній діяльності державних служґ, посадових осіб митних органів та суб'єктів підприємницької діяльності.

Викладосновногоматеріалу.Відповіднодоположень Митного кодексу України (далі - МК України) передбачено три способи розпорядження 
майном, яким митниця в установленому законом порядку набула права розпорядження, а саме: 1) реалізація; 2) безоплатна передача; 3) переробка, утилізація [2].

3 правових позицій реалізація майна є однією із ефективних форм розпорядження, оскільки дозволяє не лише звільнити складські приміщення від товарів, зекономивши кошти на їх зберігання та складські операції, людський ресурс для інвентаризації, але й поповнити державний бюджет коштами, отриманими від їх продажу. Водночас необхідно пам'ятати, що розпорядження товарами, транспортними засобами комерційного призначення в контексті діяльності митних органів є складною процедурою, наділеною рядом особливостей, притаманних саме цим адміністративно-правовим відносинам.

Слід зазначити, що серед науковців відсутній єдиний підхід відносно визначення "реалізація». У сучасній цивілістичній та господарсько-правовій доктрині більш поширеним є термін «розпорядження». Водночас категорія "реалізація майна» передбачаєобов' язковеплатнерозпорядження майном для досягнення найбільшого економічного ефекту (отримання матеріального задоволення). Коли ж ідеться про здійснення реалізації товарів, які опинилися у розпорядженні митних органів, необхідність досягнення найкращого економічного ефекту для наповнення державного бюджету під час здійснення реалізації такого майна в межах визначених законодавством процедур є бажаним результатом.

Під реалізаційною процедурою у перспективному законодавстві ще десятиліття тому пропонувалося вважати процедуру продажу майна на конкурсних засадах та конкурентній основі, за результатами якої сторонами укладається правочин про передачу майна у власність [5]. Таке визначення об'єднувало на той час як цивільно-правові елементи (вказівка на спосіб набуття права власності на майно), так і господарсько-організаційний аспект (щодо процедури продажу майна на конкурсних засадах та конкурентній основі).

У сучасному митному законодавстві не наведено визначення терміну "реалізація», але натомість у ст. 4 МК України наводиться визначення «випуск товарів», під яким слід розуміти надання органом доходів і зборів права на користування та/або розпорядження товарами, щодо яких здійснюється митне оформлення відповідно до заявленої мети [2; 4, с. 120].

Слід відзначити, що тривалий час (йдеться про період від 2003 до 2019 року) законодавство, яким врегульований порядок реалізації майна, не зазнавало змін, що негативно відображається на загальних показниках в цьому напряму. Склади митниць постійно заповнені майном, яке, з часом втрачаючи свої властивості, падає в ціні та стає комерційно непривабливим. Процедури розпорядження були занадто бюрократичними та потребували нагального спрощення.

Розглянемо ж рівень такого нормативно-правового забезпечення. Так, відповідно до п. 8 Положення (стандарту) бухгалтерського обліку 15 «Дохід» «Реалізація продукції (робіт, послуг) - це господарча операція суб'єкта підприємницької діяльності, що передбачає передачу права власності на продукцію (роботи, послуги) іншому суб'єкту підприємницької діяльності в обмін на еквівалентну суму коштів або боргових зобов'язань.

Реалізація в розумінні Закону України «Про основні принципи та вимоги до безпечності та якості харчових продуктів» №771/97-ВР від 23.12.1997 р. - це передача, обмін, поставка за договором та відчуження іншим шляхом харчового продукту від однієї особи до іншої незалежно від того, чи відбулася реалізація платно та/або в іншій формі [6].

Порядок обліку, зберігання, оцінки вилученого митницями ДФС майна, щодо якого винесено рішення суду про конфіскацію, передачі його органам державної виконавчої служби і розпорядження ним, затверджено постановою КМУ від 26.12.2001 року № 1724 [7]. Облік, попередня оцінка, а також відповідальність за зберігання вилученого митницями ДФС майна до прийняття судом рішення про його конфіскацію покладаються на ці органи. Порядок роботи складу митниці ДФС затверджено наказом Міністерства фінансів України від 30.05.2012 року № 627, зареєстрованим в Міністерстві юстиції України 03.07.2012 року за № 1097/21409 [8].

3 аналізу чинних нормативно-правових актів можна дійти висновку, що до грудня 2019 року товари (майно), набуті митними органами, могли бути реалізовані на митних аукціонах, товарних біржах або через підприємства торгівлі. Тривалий час процедура організації та умови проведення митних аукціонів, реалізації на митних аукціонах, товарних біржах або через підприємства торгівлі товарів і транспортних засобів, що перейшли у власність держави, і товарів, строк зберігання яких під митним контролем закінчився, а власник не звернувся за ними в установлений МК України строк, механізм оцінки та уцінки таких товарів i розрахунків за реалізовані товари, а також спосіб розпорядження окремими видами товарів, що не підлягають реалізації, врегульовані постановою КМУ від 26 квітня 2003 р. № 607 [9].

Сама реалізація конфіскованого за рішеннями судів майна здійснювалася відповідно до Порядку реалізації арештованого майна, затвердженого наказом Міністерства юстиції України від 29.09.2016 року №2831/5, зареєстрованого в Міністерстві юстиції України 30.09.2016 року за №1301/29431 [10], державним підприємством, 
яке належить до сфери управління Міністерства юстиції України та уповноважене відповідно до законодавства на здійснення заходів зі створення та супроводження програмного забезпечення системи реалізації арештованого майна, технологічного забезпечення, збереження та захисту даних, що містяться у цій системі, на організацію та проведення електронних торгів та торгів за фіксованою ціною, забезпечення збереження майна.

На практиці донедавна в Україні реалізацією конфіскату займається шість фірм: ПП «НИВА - В.Ш.», ПП Спеціалізоване підприємство «Юстиція», ТОВ «Юнор», ТОВ «ТД Еліт Сервіс», ТОВ «Торговий дім Укрспецреалізація», ТОВ «Кей Стоун». Всі вони були відібрані на основі конкурсу Міністерства юстиції України. Пізніше аукціони з продажу арештованого майна в Україні почали відбуватися за допомогою системи електронних торгів арештованим майном (CETAM) через мережу Інтернет. Система почала працювати в усіх регіонах України з серпня 2014 р. Система CETAM - публічна та загальнодоступна, що досягається завдяки мережі Інтернет. Участь у торгах відбувається віддалено у режимі онлайн, так само відбувається спостереження за ними. Доступ на сайт системи є вільним для усіх охочих за умови обов'язкової реєстрації. Реєстрація на сайті є безкоштовною. Інформація про умови, предмет та результати торгів доступні для будь-якої особи. Охочі придбати конфісковане майно подають заявки онлайн, основною вимогою є доступ до мережі Інтернет. Приймання заявок на участь в електронних торгах починається з моменту розміщення інформаційного повідомлення і триває до завершення електронних торгів. Кошти, які надійшли на рахунок органу державної виконавчої служби від реалізації майна, після відшкодування витрат виконавчого провадження підлягають перерахуванню до державного бюджету протягом трьох банківських днів.

Ситуація зазнала змін після вступу у дію Постанови КМУ «Про затвердження Порядку реалізації товарів на митних аукціонах, редукціонах та визнання такими, що втратили чинність, деяких постанов Кабінету Міністрів України» від 4 грудня 2019 р. № 1050 [11]. Митні аукціони проводяться сьогодні за наступною процедурою: регіональні митниці укладають договори з Операторами, через які публікують лот в Центральній базі даних ДП «Прозоро. Продажі». Замовником електронного аукціону є митниця, в якій перебуває на обліку товар, що підлягає реалізації через електронну торгову систему, і яка уклала з оператором електронного майданчика договір про проведення електронного аукціону. Аукціони проводяться за кожним окремим лотом. Дата проведення визначається за рішенням комісії. Перший митний аукціон або редукціон проводиться через
15 календарних днів, а щодо товарів, які швидко псуються або мають обмежений строк зберігання, проводиться через сім робочих днів після оприлюднення оголошення про проведення. Учасниками електронного аукціону можуть бути фізичні або юридичні особи (резидент або нерезидент) в особі уповноваженого представника. Учасники повинні сплатити реєстраційний та гарантійний внески на рахунок оператора, послугами якого вони користуються для участі в аукціоні, та пройти процедуру реєстрації для участі в аукціоні. Переможцем електронного аукціону визнається учасник, який на момент завершення електронного аукціону запропонував: найвищу цінову пропозицію, при тому, що цим учасником зроблено щонайменше один крок аукціону; наступну за величиною цінову пропозицію у разі дискваліфікації учасника, який запропонував найвищу цінову пропозицію. У разі однакових цінових пропозицій переможцем визначається учасник, яким подано цінову пропозицію раніше. За результатами аукціону формується протокол та оприлюднюється в електронній торговій системі автоматично в день його завершення. Потенційні учасники реєструються для участі в торгах через будь-якого Оператора та беруть участь в аукціоні. Переможець зобов' язаний протягом одного робочого дня перерахувати всю суму Оператору, через якого публікувався лот [11].

Оператор має протягом трьох робочих днів перерахувати кошти на рахунок відповідної регіональної митниці. Винагородою всім учасникам процесу є 5\% від ціни реалізації лоту, загалом в цю суму входить гарантійний внесок, який отримує Оператор, через майданчик якого зареєструвався на торги переможець.

Гарантійний внесок може бути більшим за винагороду, тоді різниця сплачується замовником. Якщо він менший, то Переможець доплачує відповідну суму, але загалом це завжди $5 \%$ від ціни продажу. 3 суми винагороди 5\% сплачується $30 \%$ ДП «Прозоро. Продажі» на розвиток ЕТС. Водночас з залишку суми $30 \%$ отримує Оператор, через який регіональна митниця опублікувала лот, a 70\% отримує Оператор, через який була зроблена найвища цінова пропозиція.

Реалізація майна на митних аукціонах це, безумовно, багатосторонній та складний правочин, в якому слід виділити правовідносини, що виникають між відповідним митним органом та оператором, через який публікуються лоти в ЦБД (Центральні бази даних). Ці правовідносини, враховуючи отримання оператором всієї суми за реалізацію майна, мають чіткі ознаки договору комісії з усіма податковими наслідками щодо сплати ПДВ.

Важливо відмітити, що товар, який набуває статусу такого, що підлягає розпорядженню 
митним органом, повинен відповідати вимогам, встановленим законодавством саме до такого виду товару. Якщо це продукт харчування - вимогам щодо безпеки харчування; якщо дитяча іграшка-відповідним стандартам, бути сертифікованим і так далі. Для реалізації корму для тварин повинні бути свої дозвільні документи, видані спеціальними уповноваженими органами. До прийняття рішення про передачу в реалізацію майна та вибору шляхів такої реалізації такий товар проходить зазвичай довгий шлях та бюрократичні кола погоджень та отримання відповідних дозволів. При цьому для кожного товару це свій шлях. На цей час не існує єдиної методології з цього питання. До митниць надходять лише поодинокі листи роз'яснення щодо реалізації окремих товарів.

У зв'язку з цим вважаємо за необхідне розроблення єдиних методичних рекомендацій щодо розпорядження основних видів товару, що дасть можливість на практиці оволодіти необхідними знаннями та прискорити розпорядження окремих видів товару.

Водночас сучасні нововведення не позбавлені і певних проблемних моментів. Деякі з них лежать у податковій сфері і прямо впливають на оцінку ефективності подібних електронних аукціонів. Йдеться про проблему оподаткування діяльності оператора, який проводить електронні торги. Оператор (платник ПДВ) під час здійснення операції постачання (реалізації) майна (товару) на електронному аукціоні, переданого митницею (замовником), на дату перерахування переможцем електронного аукціону коштів на його рахунок як оплати за придбане майно (товар) зобов' язаний нарахувати податкові зобов'язання з ПДВ за такою операцією відповідно до бази оподаткування, встановленої пунктом 188.1 статті 188 Податкового кодексу України, а саме з усієї суми таких коштів.

Крім того, оператор зобов'язаний нарахувати податкові зобов'язання з ПДВ на суму комісійної винагороди, отриманих як оплату вартості наданих ним послуг із постачання (реалізації) майна (товару) на електронному аукціоні. Це тягне за собою наступний наслідок: коли на митному аукціоні Оператор (платник ПДВ) уклав договір 3 митницею та опублікував лот, який було реалізовано приміром за 100000 грн, то такий оператор, отримавши 100000 грн за лот, зобов'язаний сплатити з нього 20000 грн (20\%) ПДВ та протягом 3 робочих днів перерахувати на рахунок митниці 100000 грн. Потім, отримавши від оператора, через який було подано найбільшу цінову пропозицію, свою комісійну винагороду в розмірі 1050 грн, має сплатити з них 210 грн. (20\% ) ПДВ. Таким чином, оператор (платник ПДВ) на митному аукціоні заробляє 840 грн, а тільки податку на додану вартість має сплатити 20210 грн [12]. $\mathrm{y}$ цій ситуації виникає проблема, яка вимагає вирішення виключно через застосування технікоюридичних засобів, тобто шляхом внесення змін до тексту нормативно-правового акту.

Ще одним питанням, яке залишається поза увагою нормативно-правового регулювання, є визначення переліку майна, яке не підлягає реалізації через систему митних аукціонів. Якщо у Постанові КМУ «Про затвердження Порядку організації митних аукціонів, реалізації товарів і транспортних засобів на митних аукціонах, товарних біржах або через підприємства торгівлі, а також розпорядження окремими видами товарів, що не підлягають реалізації» № 607 від 26 квітня 2003 р. такий перелік містився, то у нині діючій Постанові КМУ «Про затвердження Порядку реалізації товарів на митних аукціонах, редукціонах та визнання такими, що втратили чинність, деяких постанов Кабінету Міністрів України» від 4 грудня 2019 р. № 1050 він відсутній.

Раніше нормативний перелік включав такі товари, які не підлягають реалізації: предмети, що мають історичну, наукову, художню або іншу культурну цінність; предмети релігійного культу; лікарські та медичні препарати; наркотичні засоби, психотропні речовини, прекурсори; валютні цінності (валюта України та іноземна валюта); алкогольні напої та тютюнові вироби; товари, заборонені до реалізації в Україні згідно із законодавством; товари, включені до номенклатури матеріальних цінностей державного резерву, що затверджується Кабінетом Міністрів України, за переліком, визначеним Держрезервом [9].

Висновки. Таким чином, ми можемо наголосити на тому, що митний аукціон - це спосіб обов'язкового продажу (реалізації) товарів (майна), яке опинилося у розпорядженні митних органів з метою досягнення найкращого економічного ефекту для наповнення державного бюджету (власником товарів стає покупець, що в ході торгів запропонував за них найвищу ціну).

Враховуючи неоднозначність визначення терміну «реалізація» в науковій та юридичній літературі, вважаємо за необхідне закріпити на законодавчому рівні в митному законодавстві це поняття, що дасть можливість чітко розуміти, чи може реалізація майна бути виключно платною та/або здійснюватися в іншій формі. Із урахуванням існування в митному законодавстві окремої форми розпорядження майном у вигляді безоплатної передачі підтримуємо думку, що реалізація є виключно платною процедурою.

У межах перспектив подальших досліджень наголосимо на можливості дослідження іноземного досвіду щодо реалізації товарів (майна) митними органами та використання передового досвіду Україною. 


\section{Jimepamypa:}

1. Про Державну фіскальну службу України: Постанова Кабінету Міністрів України; Положення від 21.05.2014 № 236. Верховна Рада України. База «Законодавство України». URL: https://zakon.rada.gov.ua/ laws/show/236-2014-\% D0\% BF/ (дата звернення: 12.07. 2020).

2. Митний кодекс: Закон України від 13 березня 2012 року № 4495-VI. Верховна Рада України. База«Законодавство України». URL: http://zakon2.rada.gov.ua/laws/show/4495-17 (дата звернення: 12.07.2020).

3. Міроненко В. Право володіння, користування i розпорядження власністю за цивільним законодавством. Підприєлниитво, господарство і право. 2019. № 1. C. 28-33.

4. Публічне управління та адміністрування операцій $з$ товарами, що переходять у власність держави за порушення митного законодавств [Текст] : кол. моногр. ; за заг. ред. Прус Л.Р., Попеля С.А. Хмельницький : ФОП Мельник А.А., 2020. С. 413.

5. Про економічні засади поводження з окремими видами майна : Проект Закону України від 24.04.2009 № 4407. http://search.ligazakon.ua/1_doc2.nsf/link1/ JF3EF00B.html(дата звернення: 12.07.2020).

6. Про основні принципи та вимоги до безпечності та якості харчових продуктів : Закон України від 23 грудня 1997 року № 771/97-В. Верховна Рада України. База «Законодавство України». URL: https://zakon.rada.gov.ua/laws/show/771/97-\% D0\% B2\% D1\% 80\#Text (дата звернення: 12.07. 2020).

7. Порядок обліку, зберігання, оцінки вилученого митницями ДФС майна, щодо якого винесено рішення суду про конфіскацію, передачі його органам державної виконавчої служби і розпорядження ним: Постанова Кабінету Міністрів України; Порядок від 26.12.2001 № 1724. URL: https://zakon.rada.gov.ua/ laws/show/1724-2001-\% D0\% BF (дата звернення: 12.07. 2020).

8. Порядок роботи складу митниці ДФС: Мінфін України; Наказ, Порядок, Форма типового документа від 30.05.2012№627. URL: https://zakon5.rada.gov.ua/ laws/show/z1097-12 (дата звернення: 12.07. 2020).

9. Про затвердження Порядку організації митних аукціонів, реалізації товарів і транспортних засобів на митних аукціонах, товарних біржах або через підприємства торгівлі, а також розпорядження окремими видами товарів, що не підлягають реалізації : Постанова КМУ від 26 квітня 2003 р. № 607. Верховна Рада України. База «Законодавство України». URL: https://zakon.rada.gov.ua/laws/show/607-2003D0\% BF/print (дата звернення: 12.07. 2020).

10. Порядок реалізації арештованого майна: Наказ Міністерства юстиції України; Порядок від 29.09.2016 № 2831/5. Верховна Рада України. База «Законодавство України». URL: https://zakon.rada.gov.ua/ laws/show/z1301-16 (дата звернення: 12.07. 2020).

11. Про затвердження Порядку реалізації товарів на митних аукціонах, редукціонах та визнання такими, що втратили чинність, деяких постанов Кабінету Міністрів України : Постанова КМУ від 4 грудня 2019 р. № 1050. Верховна Рада України. База «Законодавство України». URL: https://zakon.rada.gov.ua/ laws/show/1050-2019-\% D0\% BF\#Text (дата звернення: 12.07. 2020).

12. Писанчин М. Податковий капкан для митних аукционів. URL: https://www.epravda.com.ua/ rus/columns/2020/06/24/662219/ (дата звернення: 12.07.2020).

\section{Анотація}

Князев В. С. Нормативно-правове регулювання реалізаційних процедур у діяльності митних органів україни. - Стаття.

Стаття присвячена питанням нормативно-правового регулювання реалізаційних процедур у діяльності митних органів України. Активний розвиток інформаційних технологій створює нові можливості для здійснення повноважень митних органів України у частині реалізації майна, яке перебуває у їх розпорядженні. Розпорядження товарами, транспортними засобами комерційного призначення в контексті діяльності митних органів є складною процедурою, наділеною рядом особливостей, притаманних саме цим адміністративно-правовим відносинам. Поширення нового нормативно-правового порядку проведення митних аукціонів призвело до виникнення низки важливих питань щодо ефективності зазначених процедур. Коли ж ідеться про здійснення реалізації товарів, які перебувають у розпорядженні митних органів, можемо наголосити на необхідності досягнення найкращого економічного ефекту для наповнення державного бюджету під час реалізації такого майна в межах визначених законодавством процедур.

Зазначено, що реалізація майна на митних аукціонах це, безумовно, багатосторонній та складний процес, в якому окремо слід виділити правовідносини між відповідним митним органом та оператором, через який публікуються лоти в ЦБД (Центральні бази даних). Враховуючи отримання оператором всієї суми за реалізацію майна, можна говорити, що такі правовідносини мають чіткі ознаки договору комісії з усіма податковими наслідками щодо сплати ПДВ. Наголошено, що митний аукціон - це спосіб обов'язкового продажу (реалізаціi) товарів (майна), яке опинилося у розпорядженні митних органів, з метою досягнення найкращого економічного ефекту для наповнення державного бюджету (власником товарів стає покупець, що в процесі торгів запропонував за них найвищу ціну). Враховуючи неоднозначність визначення терміну «реалізація» в науковій та юридичній літературі, вважаємо за необхідне закріпити на законодавчому рівні в митному законодавстві це поняття, що дасть можливість чітко розуміти, чи може реалізація майна бути виключно платною та/або здійснюватися в іншій формі. Із урахуванням існування в митному законодавстві окремої форми розпорядження майном у вигляді безоплатної передачі підтримуємо думку, що реалізація є виключно платною процедурою.

Ключові слова: майно, митні органи, матеріальні цінності, реалізація, розпорядження, товари, контрафактні товари, контрабанда, митні аукціони, лот.

\section{Summary}

Kniaziev V. S. Normative and law regulation of procedures of sale in activities of customs authorities of Ukraine. - Article.

The article is devoted to the issues of normative-legal regulation of realization procedures in the activity of customs bodies of Ukraine. The active development of information technologies creates new opportunities for the exercise of the powers of the customs authorities of Ukraine in terms of the sale of property at their disposal. Disposal of goods, commercial vehicles in the context of customs authorities is a complex procedure, endowed with a number of features inherent in these administrative and legal relations. The spread of the new legal procedure for conducting customs auctions has led to a number of important questions about the effec- 
tiveness of these procedures. In the case of the sale of goods at the disposal of customs authorities, we can emphasize the need to achieve the best economic effect to fill the state budget in the sale of such property within the procedures prescribed by law.

It is noted that the sale of property at customs auctions is, of course, a multilateral and complex process, in which the legal relationship between the relevant customs authority and the operator through which the lots are published in the CBD (Central Databases) should be singled out. Given the operator's receipt of the full amount for the sale of property, we can say that such legal relations have clear features of the commission agreement with all the tax consequences for the payment of VAT. It is emphasized that the customs auction is a method of mandatory sale (sale) of goods (property), which was available to customs authorities in order to achieve the best economic effect to fill the state budget (the owner of the goods is the buyer who offered the highest bid for them price). Given the ambiguity of the definition of the term "sale" in the scientific and legal literature, we consider it necessary to enshrine at the legislative level in customs legislation this concept, which will clearly understand whether the sale of property can be exclusively paid and/or otherwise. Given the existence in the customs legislation of a separate form of disposal of property in the form of free transfer, we support the view that the implementation is an exclusively paid procedure.

Key words: property, Customs Authorities, tangibles, sale, ordering about, goods, counterfeit goods, smuggling, Customs Auctions, lot. 